\title{
Bir Külltürel Miras Örneği Olarak Akşehir Evleri Cephe Düzeninde Ahşap Elemanlar
}

\author{
Wooden Elements in the Facade Layout of Akşehir Houses as an Example of Cultural Heritage
}

\section{Derya MERT KAHRAMANa}

a Doktora Öğrencisi, Erciyes Üniversitesi, Mimarlık Anabilim Dalı, Kayseri, Türkiye.

\begin{abstract}
Özet
Akşehir, köklü bir tarih ve sosyal yapılı çevresi ile kültür turizmine katkı sağlayan önemli Anadolu şehirlerinden biridir. Şehirdeki sivil mimarlık örnekleri de yaşanılan farklı dönemlerin izlerini barındıran en önemli yöresel kültür varlıklarıdır. Akdeniz, Ege ve İç Anadolu tarihi destinasyonlarının kesiştiği noktada bulunması geleneksel Akşehir Evleri'nin mimari biçimlenişine de etkide bulunmuştur. Akşehir geleneksel konut dokusu pek çok kendine özgü karakteristik özellik yanında döneminin ve bölgesinin belirleyici unsurlarını da barındırmaktadır. Bu etkileşim ve zamanla mimari anlayışta ortaya çıkan birikim, yerel halkın yaşam pratikleri, değer yargıları gibi sosyal durumlarıyla birleştiğinde geleneksel dokuda karakteristik cephe biçimlenişleri ortaya çıkmıştır. Cephe biçimlenişi için taş, kerpiç gibi yapı elemanları yanında ahşap malzemenin sıklıkla kullanıldığı görülmektedir. Strüktürel açıdan yapı statiğinde önemli rol oynarken bir süsleme elemanı olarak da ahşabın çeşitlerine rastlanmaktadır. Ahşabın kullanımları bölge ve şehir açısından yöresel mimari tarzı yansıtması yönüyle ilgi çekici olmaktadır. Bu anlamda çalışma içerisinde Akşehir Evleri'nde ahşap kullanımının bulunduğu bölge itibariyle cepheye yansımaları incelenmiştir. Yöntem olarak yapı cephelerindeki ahşap elemanların kullanım alanları ve biçimleri tablolarla ifade edilmeye çalışılmıştır. Alandaki cephe fotoğraflarıyla desteklenen çalışmada kullanım alanlarına göre ahşap elemanlar için öneriler geliştirilmiştir.
\end{abstract}

Anahtar Kelimeler: Akşehir Evleri, Cephe Biçimlenişi, Ahşap Kullanımı, Yöresel Mimari.

\begin{abstract}
Akşehir is one of the important Anatolian cities that contribute to cultural tourism with its deeprooted history and socially built environment. The examples of civil architecture in the city are also the most important local cultural assets that contain the traces of different periods. Being at the intersection of Mediterranean, Aegean and Central Anatolian historical destinations has also had an impact on the architectural formation of traditional Akşehir Houses. Akşehir's traditional housing pattern contains many distinctive characteristics as well as the determinants of its period and region. When this interaction and the accumulation that emerged in the architectural understanding over time were combined with the social situations of the local people such as life practices and value judgments, characteristic facade formations in the traditional texture emerged. It is seen that wooden materials are frequently used for the formation of the facade, as well as building elements such as stone and adobe. While it plays an important role in structural statics, wood types are encountered as an ornamental element. The uses of wood are interesting for the region and the city, as it reflects the local architectural style. In this sense, the reflections of wood usage on the facade in Akşehir Houses were examined in this study. As a method, the usage areas and forms of the wooden elements on the building facades were tried to be expressed with tables. In the study supported by the facade photographs in the area, suggestions were developed for wooden elements according to their usage areas.
\end{abstract}

Keywords: Akşehir Houses, Facade Formation, Use of Wood, Local Architecture.
Makale Bilgisi

Geliş Tarihi

17.08.2021

Kabul Tarihi

Sayı Editörü

Sağbetullah MERİÇ

Sorumlu Yazar

Derya Mert Kahraman derya.mert.mim@gmail.com $@$

\section{Önerilen Atıf:}

Kahraman, D. M., (2021). Bir Kültürel Miras Örneği Olarak Akşehir Evleri Cephe Düzeninde Ahşap Elemanlar. Journal of Academic Tourism Studies, 2(2): 42-53. 


\section{GİRIŞ̧}

Kentin kültürel kimliği, o kentte yaşayan nüfusun büyüklüğü, bu nüfusun sinıfsal özellikleri, alışkanlıkları, yaptıkları meslekler ve bununla bağlantılı ilişkiler ağı tarafından etkilenir. Başka bir deyişle, kent kültürünün yaratılmasında, kent sınırları içinde oturan, onun dükkân ve bürolarında görev yapan, endüstrisinde çalışan ve el sanatlarıyla uğraşanların etkinlikleri rol oynar (Bookchin, 1999). Kent kimliklerinin önemli belirleyicileri genelde yerleşimlerin tarihi dokuları içinden çıkmaktadır. Bunlara kaleleri, eski sarayları ya da özgün, yöresel konut dokuları ile geleneksel işlev alanlarını örnek verebilir. Kentlerin yerleşik alanları içinde kalan tarihsel dokular, iyi korunduğu ve kent ile uyumlu bütünleşmeyi sürdürebildikleri ölçüde, kentsel çevrenin kalitesine önemli ölçüde katkı sağlarlar. Kentler ancak geçmişten geleceğe uzanan tarihsel sürekliliklerini sağlayarak, kültürel miraslarını koruyabilirler. Hızla yoğunlaşıp yaygınlaşan, değişen, sağlıksız büyüyüp yetersizleşen kentler bunu başaramaz. Bu kentler özgün kimliklerini yitirir, zamanla tanımsız mekanlar bütününe dönüşürler. Çağımızda, özellikle küreselleşmenin mekâna yansımasının göstergeleri olarak, farklı coğrafi ve ekonomik mekanlardaki kent parçalarının, giderek birbirlerine benzeşim sorunu yaşadığı gözlenmektedir (Kiper, 2006).

Büyük kentlerin tarihsel geçmişi, uluslararası turizm piyasasında 'seyirlik' mekanlar ve yapılarda somutlaştırılıp pazarlanmaya ve tüketilmeye başlanmıştır. Bir kentin ne denli uzun ve zengin tarihsel geçmişi varsa, o denli kolayca fotojenik görüntülere dönüştürülüp, renkli broşürlerde, cep kitapçılarında, dergi sayfalarında, televizyon ekranlarında satışa sunulabiliyor (Öncü ve Weyland, 2007). Kentin fiziksel yüzünü belirleyen ana bileşenin mimari yapılar olduğu açıktır. Kentsel mimarinin insanlar üzerindeki etkisi, çekicilik yaratması birçok ünlü marka kent örneğinde görülmektedir. Bunun yanı sıra marka kentler sınıfına henüz girememiş fakat diğerleri kadar potansiyel taşıyan ve UNESCO Dünya Mirası listesine alınan bazı kentler de vardır. Tipik bir kent mimarisi bu kentin kolaylıkla hatırlanmasını, fark edilmesini, benzerlerinden ayırt edilmesini sağlar. Konutlar ve kurumsal binalar kentin bina-yapı stoğunu yaratmaktadırlar. Bu yapı stoğu kentin algılanışı ve imgesini önemli ölçüde belirlemektedir (Yayınoğlu ve Susar, 2008). Özellikle karakteristik konut dokusu barındıran tarihi kentlerde cephe biçimlenişi ve cephede kullanılan elemanlar yapı için bir imge değeri taşımaktadır. Kente gelen misafirler ve daha önce bu konut dokusuna rastlamamış olan kentliler için ilgi çekici olarak onların yapıyla ilgilenmesini sağlamaktadır. Tarihi dokuda bulunan her bir konut cephesiyle ilgili bu durum düşünüldüğünde bir konutun cephe elemanıyla başlayan bu süreç dokunun tamamına olan ilgiyi arttırmaktadır. Şenyiğit'e göre cephe, "kent mekanının çeperidir ve bu anlamda cepheler kentsel mekanları sınırlandıran öğelerdir." Bu bağlamda cephe, yalnızca yapıya ait değil, kente ait bir öğedir. Dolayısıyla cephedeki elemanlar, tasarım ögeleri ve detay elemanları da kentin öğesi sayılmalıdır (Şenyiğit, 2010).

\section{ARAŞTIRMA ALANININ ANALIZII}

Araştırma alanı olarak Akşehir ilçesinin kentsel sit alanında bulunan tarihi sokakları seçilmiştir. Bu tarihi doku genel olarak ilk yerleşim alanları olan Sultandağları eteklerşnde bulunmaktadir.

\subsection{Akşehir Konumu ve Özellikleri}

Akşehir'de ilk yerleşimin neolitik çağda başladığı, bölgede yapılan yüzey araştırmalarından anlaşılmaktadır (Özsait, 1992). Strabon, Coğrafya adlı kitabında kentin bulunduğu bölgeyi, "Phrygia Paroreia" olarak adlandırmaktadır. Aynı kitapta; "Bu bölge doğrudan batıya uzanan bir çeşit dağ silsilesine sahiptir ve eteklerinde her iki tarafa geniş bir ova uzanır. Ovanın yakınlarında bulunan kentler; kuzeye doğru Philomelion (Akşehir) ve öte tarafta Pisidia yakınındaki Antiokheia (Yalvaç) denen kentler bulunur. Philomelion, tamamiyla ovadır." demektedir. Günümüz Akşehir'in bulunduğu konum itibariyle, Sultan Dağlarından gelen erozyon tabakasının üzerine kurulduğundan, dağ eteği gibi görülmektedir. Helenistik Çağda, Galat halkının yerleştiği ve 
yöreye Galatia dendiği halde, tarihsel bir alışkanlıkla Phrygia adının kullanılması alışkanlık haline gelmiştir (Umar, 1993).

Osmanlı İmparatorluğu Dönemlerinde, Akşehir'in yüzyıllar boyunca gördüğü yağma ve istila sona erdikten sonra şehir uzun yıllar ticaret ve yollarının kavşağı konumunda bulunması nedeniyle, ilk kez bu dönemde avantajlı durum haline gelmiştir. Yavuz Sultan Selim, Safevi Hükümdarı Şah İsmail üzerine yaptığı bir seferde Akşehir'de 8 yıl kalmıştır. IV. Murad'ın Bağdat Seferine çıktığı zaman Akşehir'e uğradığı ünlü gezgin Evliya Çelebi 'nin, tek Osmanlı eseri olan, İmaret Camiinin son cemaat yerinde bulunan sütun bileziği üzerine kazıdan anlaşılmaktadır. Osmanlının Gerileme Dönemi'nde Kavalalı Mehmet Ali Paşa kumandasındaki Mısır Ordusu da Akşehir üzerinden Konya'ya kadar ilerlemiş ve ordunun bir bölümü kışı Akşehir'de geçirmiştir. Bu olaylar, Akşehir'in Osmanlılar Döneminde de ticaret yolları üzerinde önemli bir ticaret merkezi oluşunun göstergesidir (Demirci, 1998).

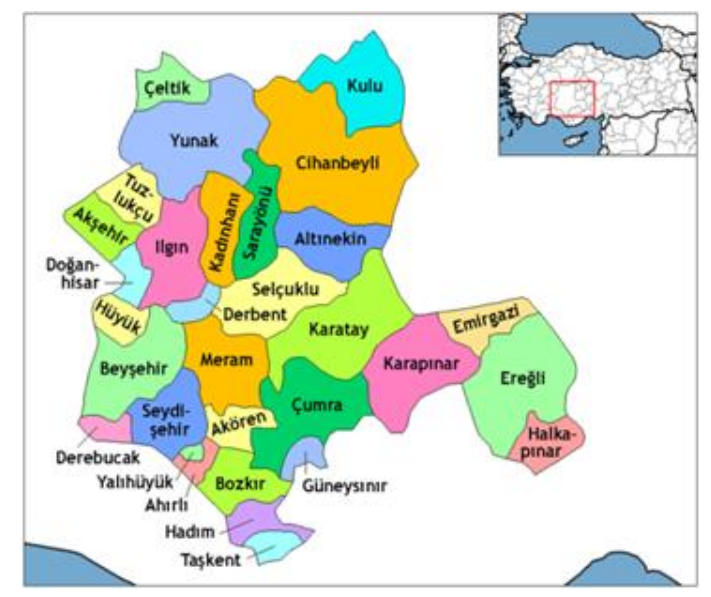

Fotoğraf 1. Akşehir' in haritadaki yeri (Vikipedi)

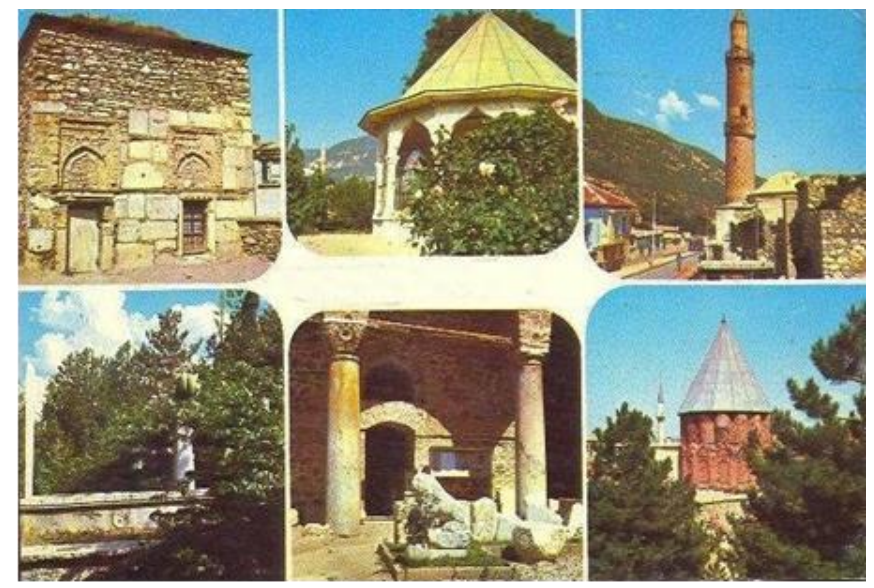

Fotoğraf 2. Akşehir'in bazı tarihi yapıları

Akşehir'i köklü tarihi ve sosyal yapılı çevresi ile bir kültürel miras örneği olarak görmek mümkündür. Farklı dönemlerin izlerini barındıran yöresel kültür varlıkları ile Akdeniz, Ege ve İç Anadolu tarihi destinasyonlarının kesiştiği bir alanda bulunmaktadır. Tüm bu tarihi veriler ve kültürel etkileşimler sonucunda geleneksel dokusunda kendine özgü biçimlenişleri görebilmekteyiz. Bu karakteristik özellikler yerel halkın yaşam pratikleri, değer yargıları gibi sosyal durumlar için ipuçları barındırmaktadır. Örneğin; geleneksel konutlardaki giriş kapısı yanında bulunan 'kimgeldi' pencereleri ile güvenlik açısından sıkıntı çekmeden gelen misafir kolaylıkla görülebilmektedir. Karakteristik cephe biçimlenişi ve cephe elemanları ile kente gelen misafirler için de ilgi çekici olmaktadır. Özellikle dönemin malzemesi olarak kullanılan ahşap elemanlarda yöresel mimari tarzı görebilmek mümkündür.

\subsection{Geleneksel Akşehir Evleri'nde Malzeme Kullanımı}

Mimari yapı, kullanım amacına uygun malzemenin uygun teknik ve yöntemlerle biçimlendirilmesi sonucu gerçekleşir. Biçim elde ederken izlenen yolların tümü (malzemeye şekil verme, işlem uygulama, bağlama, birleştirme) şeklinde tanımlanabilecek yapım, öncelikli olarak kullanılan malzemenin fiziksel özellikleri ve teknik olanaklarca yönlenen bir süreçtir. Mimarlığın ilk örneklerinden başlayarak çağdaş strüktür sistemlerinin başlangıcı olarak kabul edilen çeliğin yapıda kullanılması ve betonarme iskelet sistemlerin geliştirilmesine kadar olan süre içinde kullanılan geleneksel yapı malzemeleri, doğal taş, toprak ve ahşaptır (Ünal, 2017). 


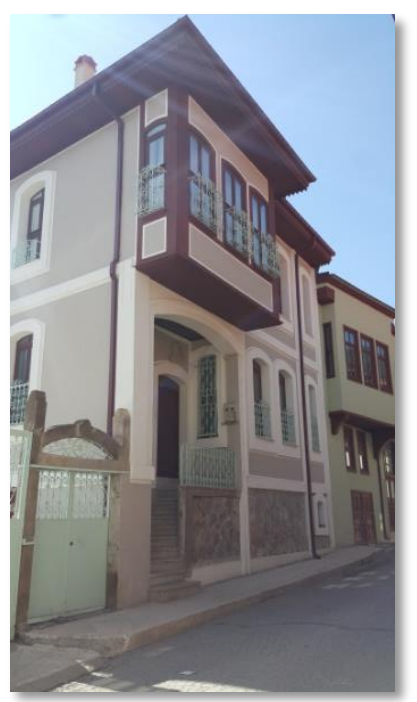

Fotoğraf 3. Değirmen Sokak 143-56 parsel (kişisel arşiv, 2015)

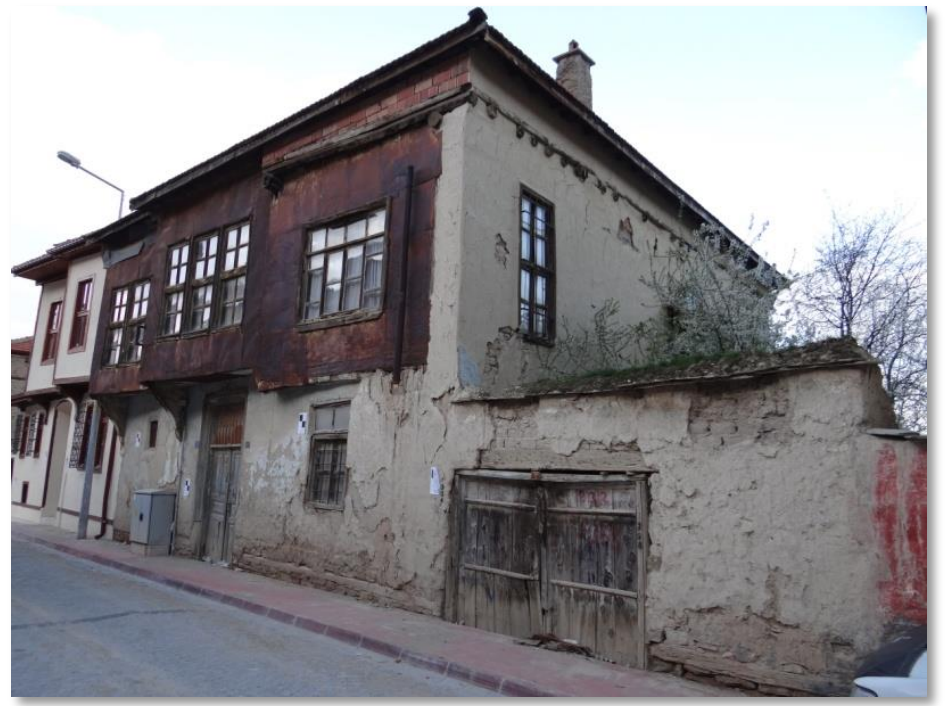

Fotoğraf 4. Hacı Hamza Sokak 136-23 parsel (kişisel arşiv, 2020)

Geleneksel Akşehir Evleri'nde de yapı malzemesi olarak taş, toprak, tuğla, ahşap, kerpiç malzemeler kullanılırken cephe elemanı olarak taş, tuğla, ahşap, ferforje demir parmaklık ve korkuluk gibi malzemeler yanında yardımcı eleman olarak sac malzeme ile renklerin kullanımıla oluşturulan hareketli biçimlenişler kullanılmaktadır.

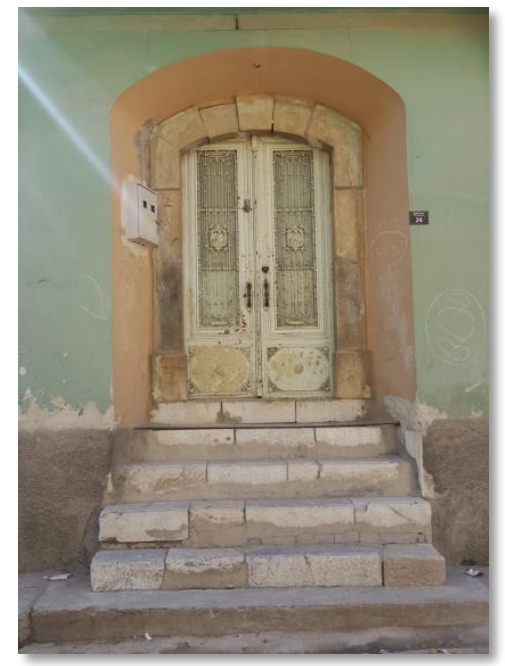

Fotoğraf 5. Taşoluk Sokak 143-25 parsel (kişisel arşiv, 2016)

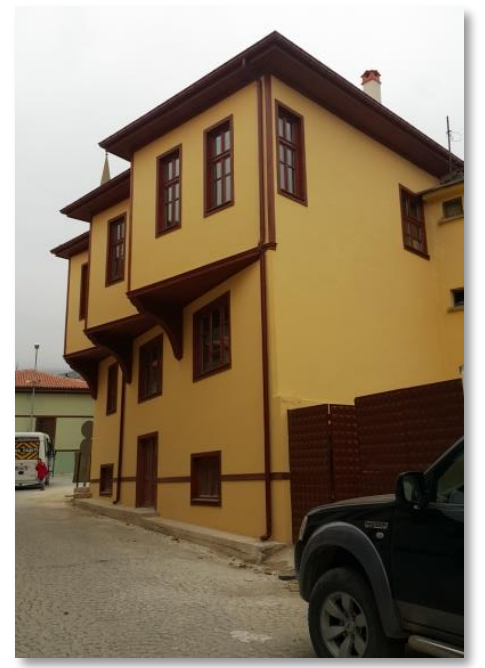

Fotoğraf 6. Ulu Cami Caddesi 150-28 parsel (kişisel arşiv, 2017)

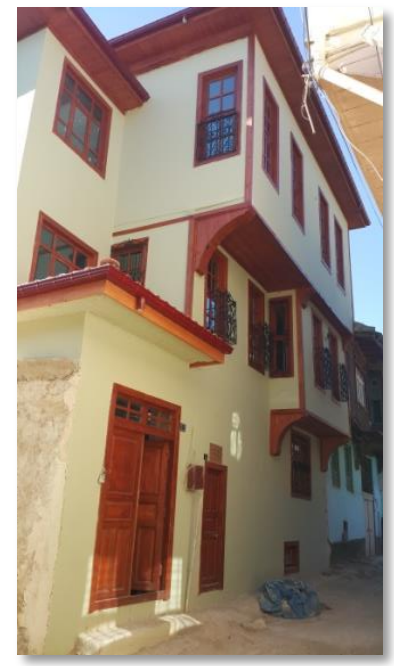

Fotoğraf 7. Tuna Sokak 143-21 parsel (kişisel arşiv, 2017)

\section{3. Çalışmaya Konu Evlerin Konumu ve Cephe Düzeni}

Eski Akşehir evleri genelde ilk yerleşme alanı olan Sultan Dağlarının eteklerinde kurulmuş mahallelerde görülmektedir. Akşehir Sit alanındaki kentsel dokuya zenginlik katan evler, üslup açısından üç grupta toplanabilir. Birinci grupta klasik Anadolu evleri olan 1-2 katlı düz toprak damlı, kerpiç yapılı erken dönem kerpiç evler, ikinci grupta; Osmanlı dönemi yapı geleneğinin tipik örneği olan, 2-3 katlı kırma çatılı, kiremit örtülü, cumbalı, taş subasmanlı evler, üçüncü grupta ise; Barok üslup özellikleri taşıyan, yuvarlak, süslemeli pencere ve kapı düzeni olan, üçgen alınlı, kırma çatılı, geç dönem evler yer almaktadır (Karaman, 1998). 


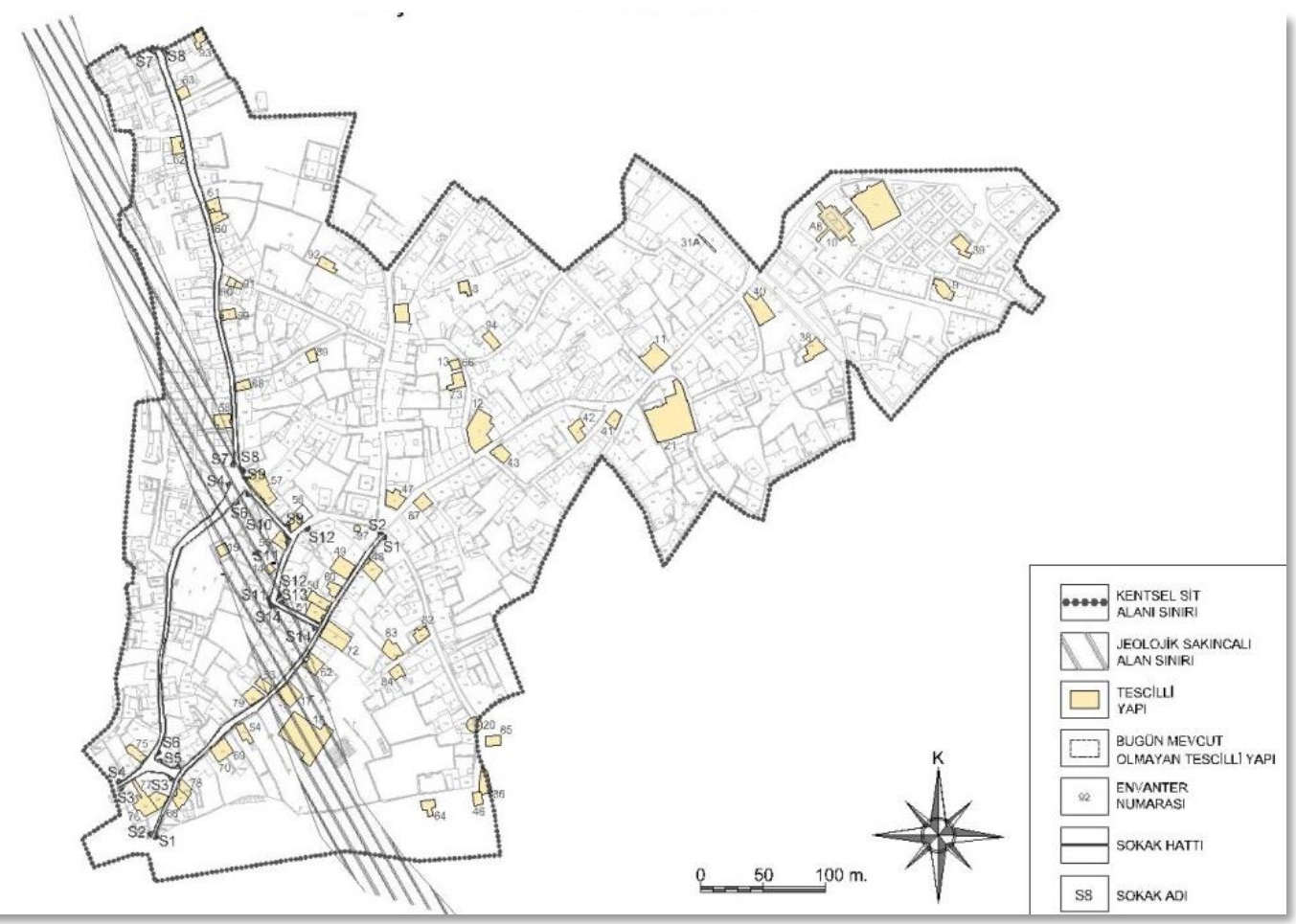

Şekil 1. Akşehir Kentsel Sit Alanı Haritası (Konya Kültür Varlıkları Koruma Bölge Kurulu)

Akşehir Evleri genellikle tek oda-sofa türünden başlayarak yan sofa ve orta sofa etrafındaki odaların oluşturduğu plan çeşitlilikleri gösterir. Genelde yan sofa ve orta sofa etrafında dizili odalardan oluşan üst kat planları bir yandan, sokağa cumbalar aracılığı ile bakıp sosyal iletişimi, öte yandan bahçe ve avlusuna bakarak doğa ile bütünleşmeyi sağlarlar. Ayrıca at ağılı, samanlık, serpin ve kiler evlerde bulunan diğer fonksiyon alanlarıdır. Akşehir eski evlerinin iç mimarisi oldukça zengindir. Ağaç malzemenin ağırlık verildiği iç mimari, günlük yaşamı düzenleyecek biçimde şekillenmiştir. Bol miktarda dolap, sedir, oyma yüklük bulunmaktadır. Usta, ahşap malzemeyi özenle adeta dantela gibi işlemiş, ona estetik değer kazandırmıştır. Uzun süreli çadır yaşamı süren Türkler, yerleşik hayata geçtikleri sırada eski değerleri yeni koşulların öğeleri ile birleştirmişlerdir. Bu nedenle evlerin iç ve dış duvarlarında yer alan ahşap işlemeli kuşaklar ve dolap üzerinde görülen süsler, çadır içi süslemenin uzantısından başka bir şey değildir. Dolap, hücre, yüklük, sedir, ocak bir oda içinde bütün oluşturur (Gençer, 1995).

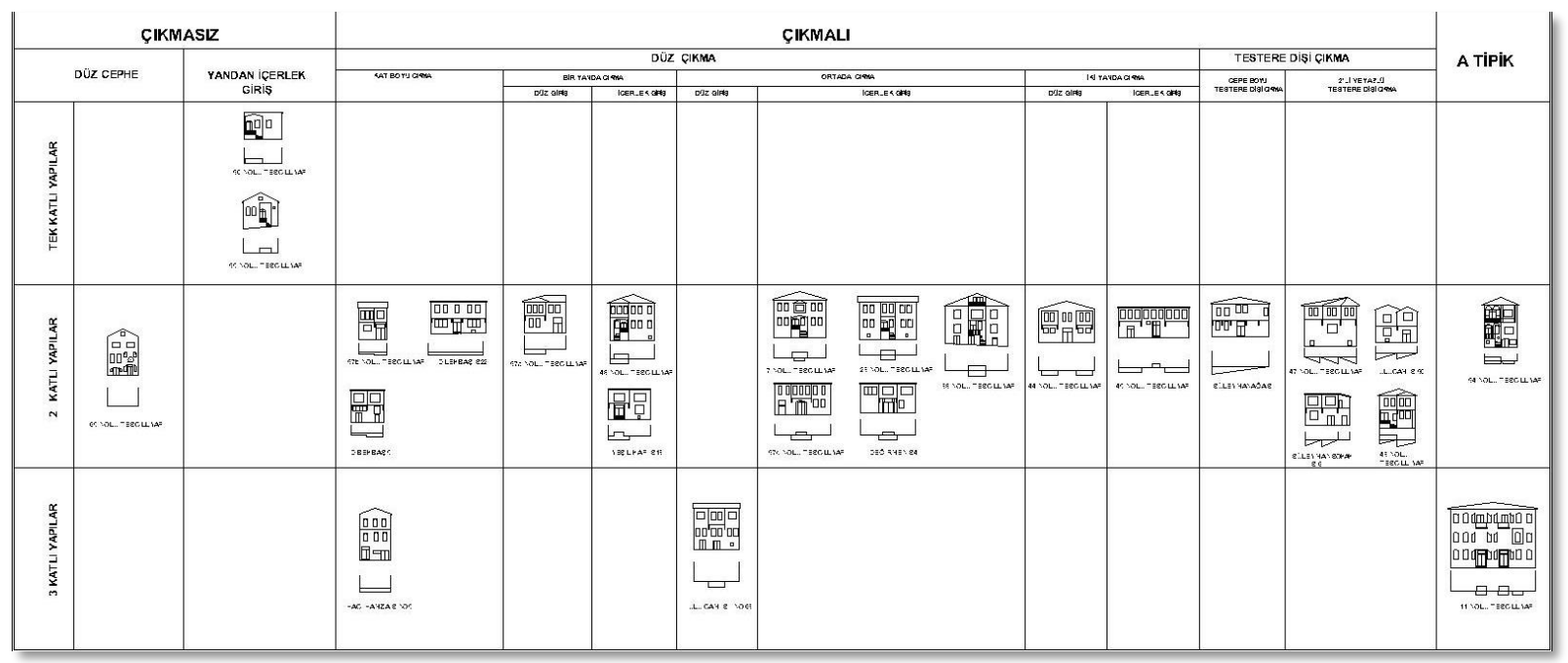

Şekil 2. Akşehir Evleri Cephe Düzeni Tipolojisi (Koruma Amaçlı İmar Planı Kentsel Tasarım Rehberi, 2009) 
1970'li yıllarda ülke çapında başlayan korumacılık anlayışı Akşehir'de de yansımalarını bulmuş 1975 yılında ilk defa profesyonel anlamda Akşehir'de uzman kişiler denetiminde ilçe merkezinde adları ve adresleri bildirilen 38 adet taşınmaz korunması gerekli eski eser olarak tespit edilmiş ve 5805 ve 1741 sayılı kanunla teşkil edilen Gayrimenkul Eski Eserleri ve Anıtlar Yüksek Kurulunun 11/02/1977 gün ve A-323 sayılı kararıyla onanmıştır (Anonim, 1975).

\subsection{Ahşap Elemanların Kullanım Alanları}

Ahşap yapının temelden çatıya kadar her bölgesinde kullanılan geleneksel yapı elemanıdır. Cephe anlamında ahşap elamanlara bakıldığında ise;

- Yapi elemanı olarak

- Mimari eleman olarak

- Cephe süs elemanı olarak

- Kaplama malzemesi olarak

- Çatı elemanı olarak kullanıldıkları görülmektedir.

\subsubsection{Yapı Elemanı Olarak}

Akşehir ilk yerleşim alanındaki tarihi konutlarda taşıyıcı sistem genellikle bodrum ve zemin kattaki taş yığma tekniği üzerinde boşluklu ahşap karkastır. Konutlarda taşıyıcı dikmeler genellikle kareye yakın kesitlidir. Bu dikmelerin araları daha ince dikey ve yatay elemanlarla desteklenmiştir. Ayrıca duvarlarda sistemin rijitliğini sağlamak ve dengesini korumak üzere taşıyıcı dikmelerle aynı en kesite sahip çapraz elemanlar kulᄀlanılmıştır. Taşıyıcı sistem yapıların biçiminden bağımsızdır. Kat adedi farklı olan çeşitli türdeki geleneksel konutlarda da aynı sistem görülebilmektedir. Bu taşıyıcı elemanlar çivi ile birbirine tutturularak karkas sistemi tamamlanmaktadır. Bu açıdan ahşap eleman yanında kullanılacak türüne uygun çivi de önem arz etmektedir. Çünkü taşıyıcı karkas sistem için daha kalın ve sağlam olanlar tercih edilmektedir.

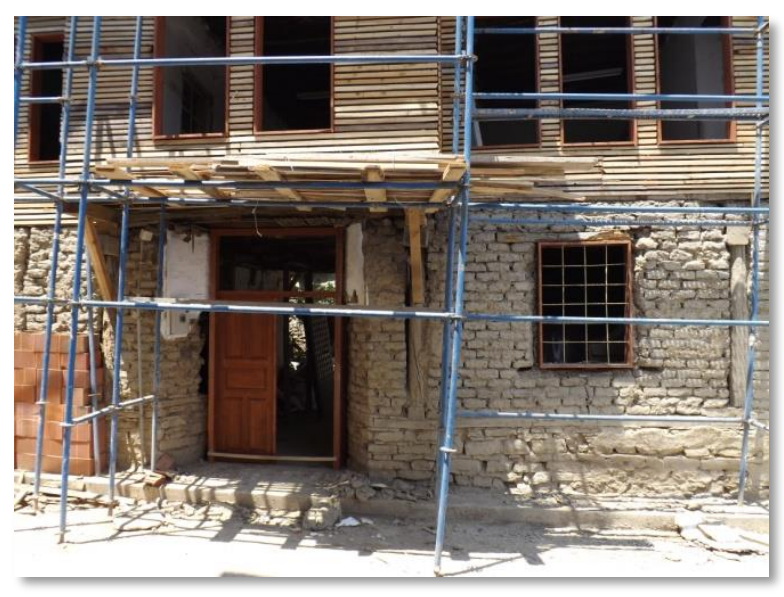

Fotoğraf 8. Değirmen Sokak düşey taşıyıcı ahşaplar (kişisel arşiv, 2015)

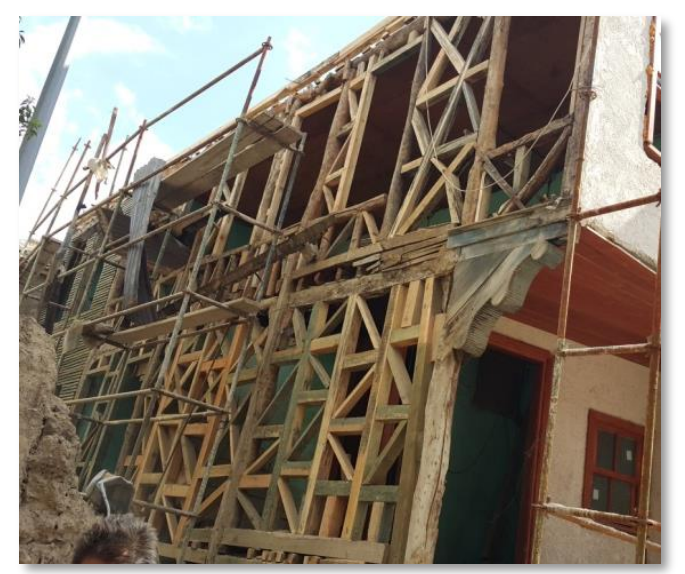

Fotoğraf 9. Ulu Cami Caddesi ahşap karkas (kişisel arşiv, 2016)

Fotoğraf 8 ve 9 'da görüldüğü üzere farklı kentsel sit alanındaki sokaklarda ahşap elemanlar yapıların düşey taşıyıcısı veya ahşap karkas parçası olarak sıva altlarında taşıyıcı görevi görmektedir. Cephelerde sadece süsleme elemanı olarak detaylarda değil yapının ana taşıyıcısı olarak da rol aldıkları anlaşılmaktadır. 


\subsubsection{Mimari Eleman Olarak}

Akşehir Evleri'nde dönem özelliklerini yansıtan önemli cephe elemanlarından kapı- pencere açıklıkları, merdiven, korkuluk, ışıklık gibi detaylar da cephe algısını etkilemektedir. İç mekân plan şemasına gore şekillenen cephedeki açıklıklar kapı ve pencereler olarka değerlendirilirken bu elemanların farklı işçiliklerle zengin bir kültür haline dönüştüğü görülmektedir. Farklı ebat ve formlarda eğrisel, çizgisel ve yuvarlak şekillerde pencereler, kemerli veya dörtgen formlu tek kanatlı, çift kanatlı kapılar ile sahanlıklı, sahanlıksız giriş merdivenleri ile bunların korkulukları bulunmaktadir.

Giyotin ve aç1lır tarzda olmak üzere çeşitli örnekleri bulunan pencereler son dönemlere doğru mahremiyet duygusundan uzaklaşarak çevreyi rahat görmeye yarayan büyük ebatlı pencerelere dönüştürülmüştür. Pencere oranları genellikle $1 / 2$ olmakla beraber $3 / 4$ oranlı ve çeşitli ebatlarda cephe pencerelerine rastlamak mümkündür. Kullanıcı maddi durumuna göre de bu pencereler ve camların boyutları farklılık göstermektedir. Tepe pencereleri de kare ya da yuvarlak olarak çeşitlilik barındırmaktadır.

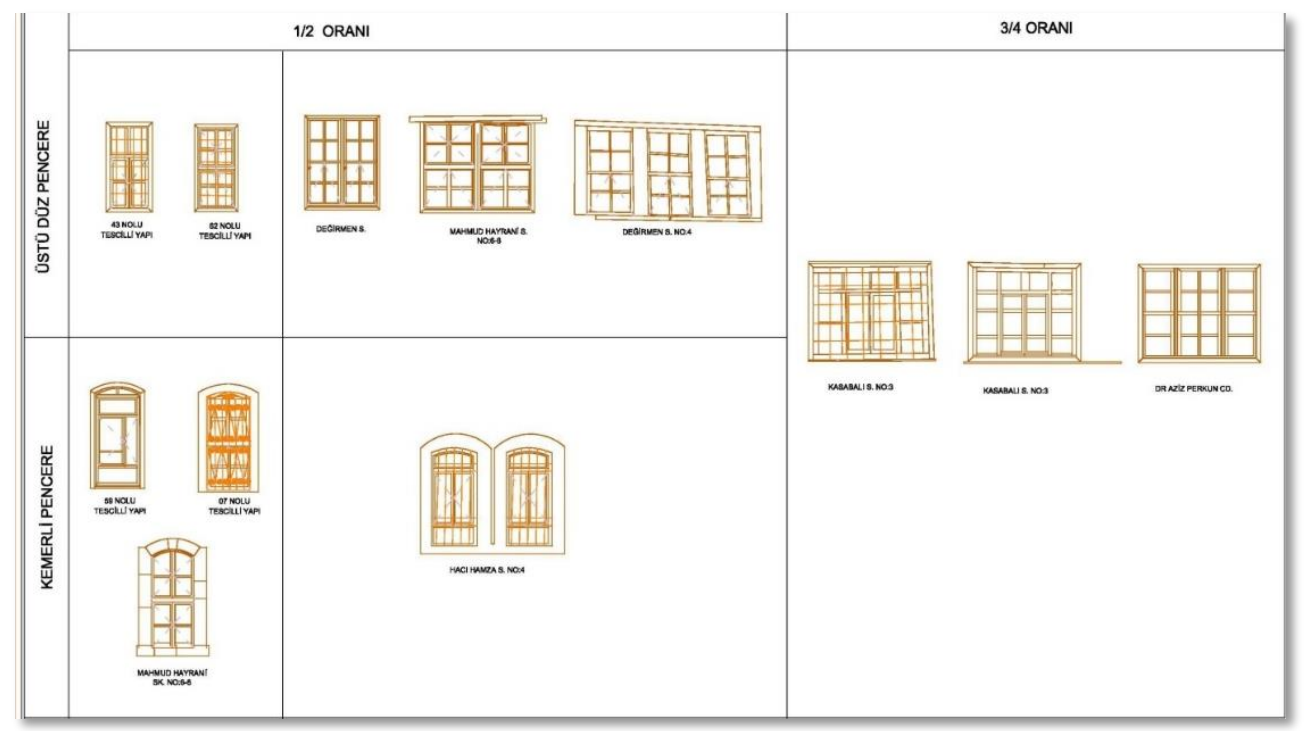

Şekil 3. Akşehir Evleri pencere tipolojisi (Kentsel Tasarım Rehberi, 2009)

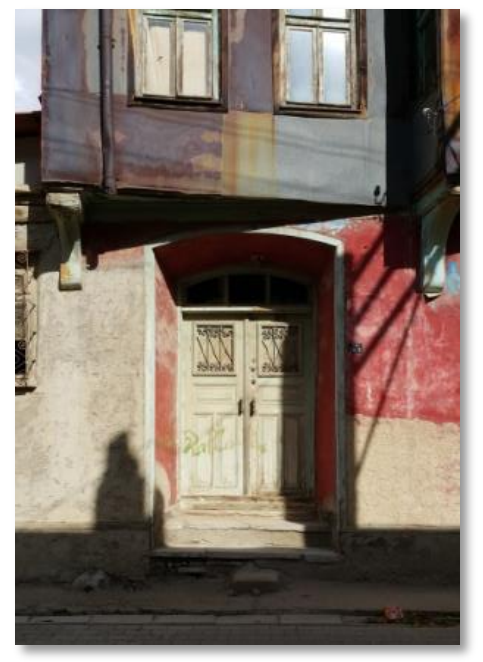

Fotoğraf 10. Hacı Hamza Sokak ahşap kapı (kişisel arsiv, 2016)

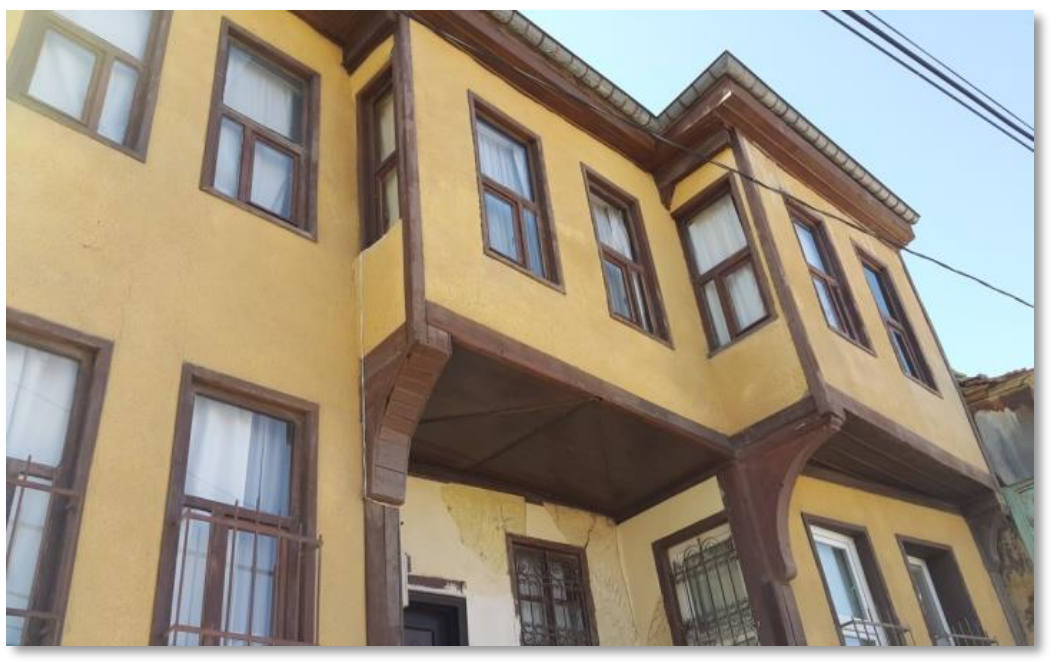

Fotoğraf 11. Taşoluk Sokak ahşap pencereler (kişisel arşiv, 2016) 


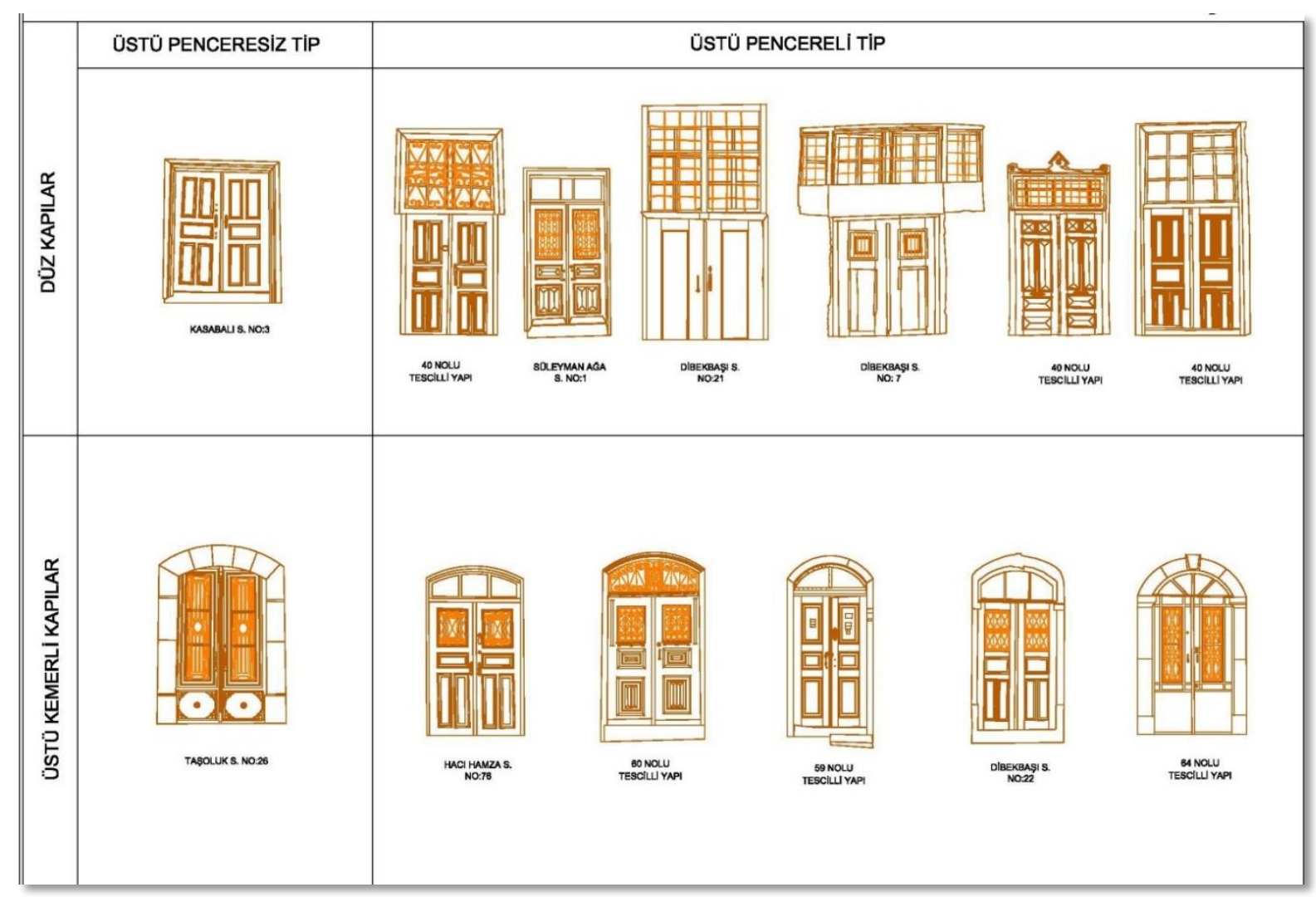

Şekil 4. Akşehir Evleri kapı tipolojisi (Akşehir Kentsel Tasarım Rehberi ,2009)

Akşehir tarihi dokusunda kapılar da özel bir önem arz etmektedir. Çünkü özellikle giriş kapıları belirli bir stili yansıtan tipik cephe elemanlarındandır. Tek ve çift kanatlı örneklerinde tablalı olarak konut giriş kapıları ile bahçe kapıları görülebilmektedir. Ayrıca gerekli kısımlarda ve kişisel isteğe bağlı olarak kapı kanatları üzerinde pencerelere de rastlanmaktadır. Giriş kapıları genellikle çift kanatlı ve üzerinde ya da yanlarında pencere bulunan iç mekânda giriş alanını aydınlık yapmaya yarayan formdadır. Bazı örneklerde de giriş kısmının merdiven ve basamaklarla yükseltilerek gösterişli girişlerin sağlandığı bilinmektedir.

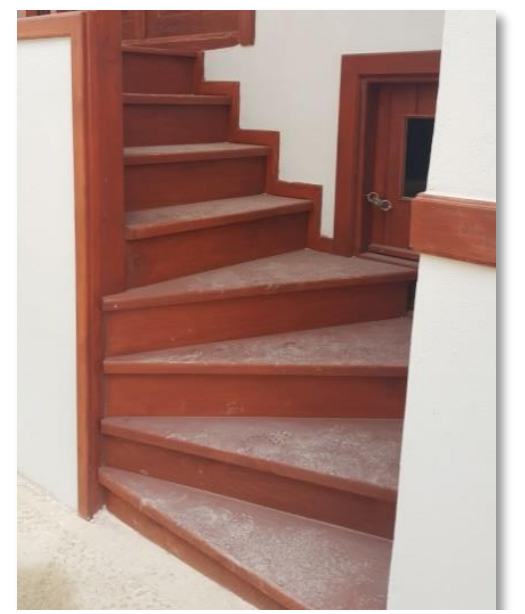

Fotoğraf 12. Ulu Cami Caddesi ahşap merdiven (kişisel arşiv, 2016)

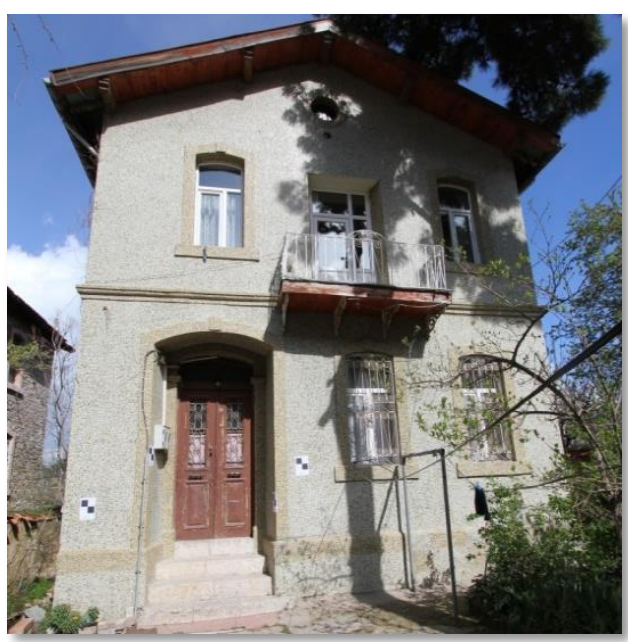

Fotoğraf 13. Hacı Hamza Sokak ahşap tepe penceresi (kişisel arşiv, 2015)

Belirli bir dönemin sanat anlayışına ışık tutan mimari yapı cephelerinde ahşabın kullanım alanları oldukça fazladır. Fotoğraf 12 'de görüldüğü gibi dış mekân giriş merdivenlerinde ve Fotoğraf $13^{\prime}$ teki çatı arasını aydınlatan yuvarlak tepe penceresinde de kullanılmıştır. 


\subsubsection{Cephe Süs Elemanı Olarak}

Örnekleri çok çeşitli şekilde sıralanabilecek olan ahşap cephe elemanlarından biri de süs elemanlarıdır. Özellikle balkon ve cumbaların taşıyıcı sisteme göre konsol, eliböğründe gibi elemanlarla desteklendiği cephelerde yük dağılımı sağlanırken cephenin de algisı değiştirilmektedir. Kat silmeleri, beden duvarının saçakla bağlantısının sağlandığı alın silmesi ve kornişleri, cumba etrafını çevreleyen kuşaklamalar, yapı bağlantı elemanları arasındaki süslemelerle cepheye yoğun bir etki katılmaktadır.

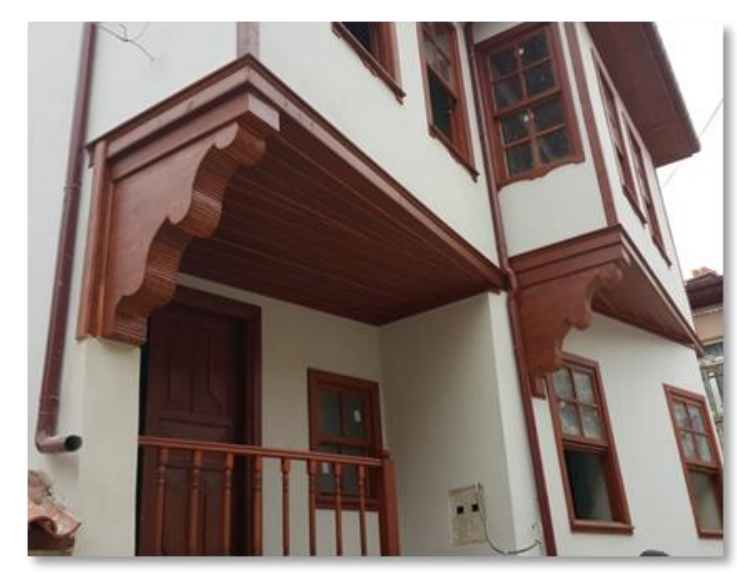

Fotoğraf 14. Ulu Cami Caddesi ahşap eliböğründe (kişisel arşiv, 2016)

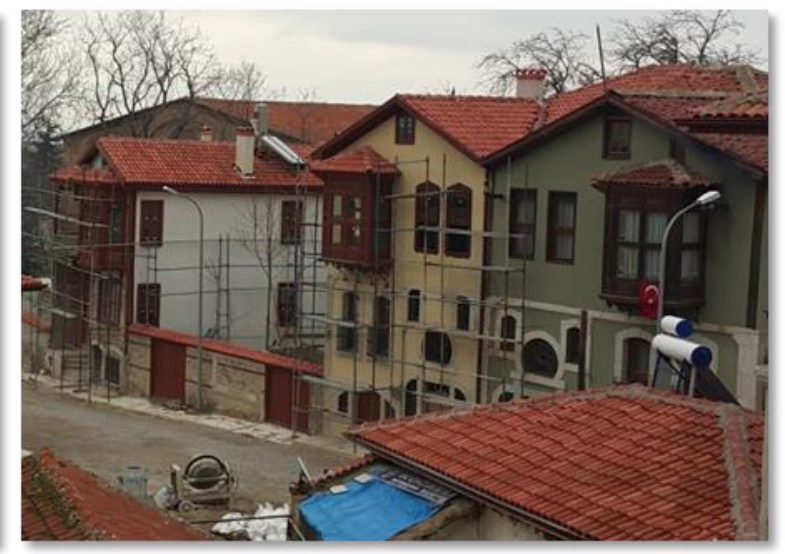

Fotoğraf 15. Değirmen Sokak ahşap cumba ve ikiz binalar (kişisel arşiv, 2016)

Çıkma ve saçaklarda bulunan ahşap elemanlarda görülen işleme ve bezemeler çok çeşitli olarak karşımıza çıkabilmektedir. Bezemelerdeki figürler ayrı ayrı küçük parçaların birleştirilmesiyle oluşturulmaktadır. Süsleme elemanları cephelerde uygun olan her alanda kullanılmıştır. Saçaklar, silmeler, balkonlar, pencere ve kapı pervazları, duvar köşeleri, boşluk alanlar gibi çeşitli yerlerde bezeme örnekleri mevcuttur. Bu bezeme $\neg$ lerde, Selçuklular ve Osmanlılar tarafından geliştirilen, geçmişi 9. yüzyıla kadar giden oyma, kakma, geçme teknikleri görülmez. Maliyet, üretim kolaylığı, yapım süresinin sınırlı oluşu, biçim özellikleri, dış etmenlere açı oluş gibi nedenlerle daha basit yöntemlere başvurulmuştur (Ciner, 1982).

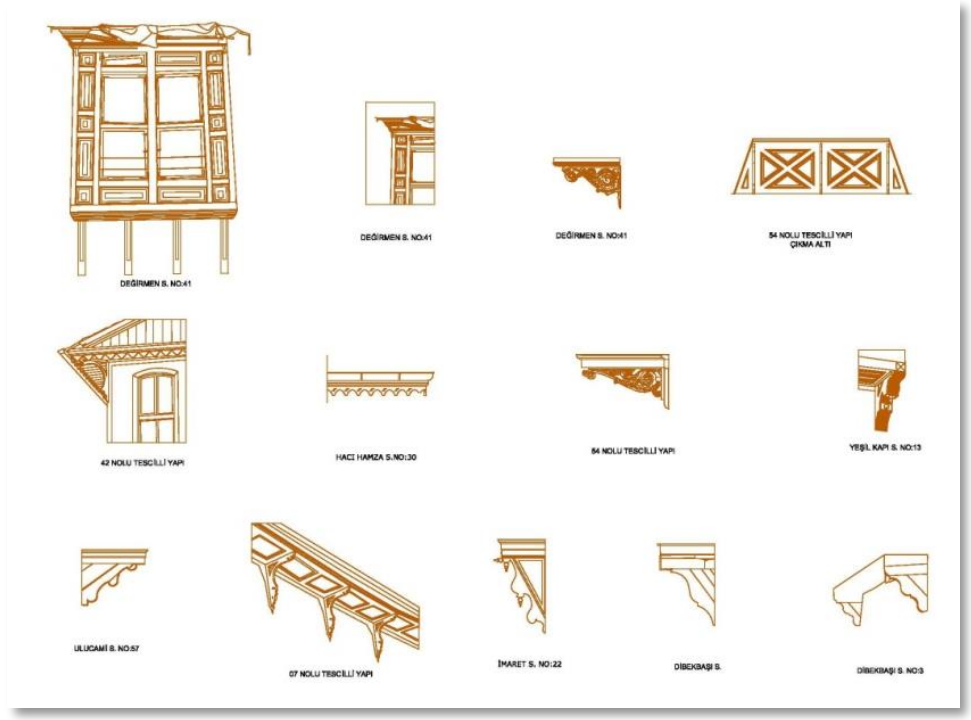

Şekil 5. Cephe Çıkma ve Saçak Detayları (Akşehir Kentsel Tasarım Rehberi, 2009) 
Cephede süs elemanı olarak kullanılan ahşapların kullanım alanları ve kullanım şekilleri 2009 yılında Akşehir Kentsel Tasarım Rehberi hazırlanırken tablo haline getirilmiştir. Bu tabloya bakıldığında cumba yüzeyleri, cumba altları, eliböğründeler, üçgen alın kaplamaları olan ahşap eleman örneklerini görmek mümkündür.

\subsubsection{Kaplama Malzemesi Olarak}

Ahşap karkas taşıyıcı sistemde olan özellikle cumbalarda taşıyıcı ahşapların üzerine bağdadi çıtaları çakılarak sıva için duvar hazır hale getirilmektedir. Bu bağdadiler restorasyonu yapılırken daldırma usulü koruyucu emprenye ile dayanıklılı̆̆ı artırılmış malzemeden tercih edilmektedir. Cephede süs elemanı olarak da gruplandırılabilecek şekilde ahşap kat silmesi, köşe pervazları da duvar birleşimlerini kapatırken binanın düşey ve yatay olarak algısını değiştirmektedir.

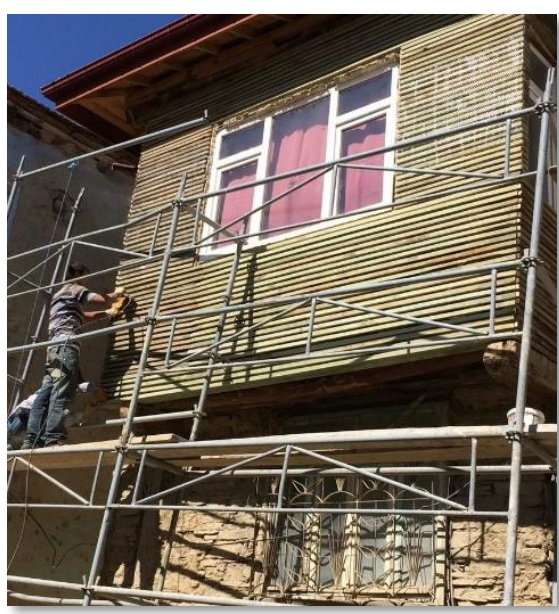

Fotoğraf 16. Yokuşbaşı Sokak cephe bă̆dadi kaplama (kişisel arşiv, 2018)

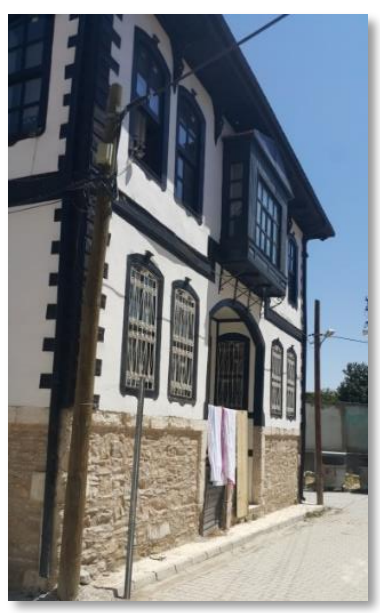

Fotoğraf 17. Tabakhamam Sokak kat silmesi (kişisel arşiv, 2017)

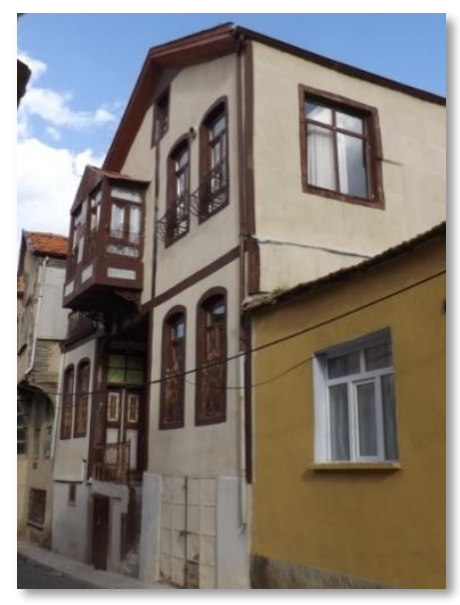

Fotoğraf 18. Değirmen Sokak ahşap köşe pervazları (kişisel arşiv, 2015)

Fotoğraflardaki örneklerde de görüldügüü üzere köşe birleşimlerinde kaplama malzemesi olarak kullanılan ahşaplar genellikle 10 ile $15 \mathrm{~cm}$ arasında değişen tek parça halinde yapılırken, birleşim kısımlarında gerek görülen alanlarda 45'lik dip çıtaları kullanılmaktadır. Cumba ve balkon altları da bina iç mekân tavanlarında olduğu gibi çıtalı ahşap kaplama olarak görülmektedir.

\subsection{5. Çatı Elemanı Olarak}

Geleneksel Akşehir Evleri'nde çatılar genel olarak kırma ya da beşik formdadır. İkisinin bir arada kullanıldığı birleşik çatıları da görmek mümkündür. İlk dönem klasik evlerinden Barok döneme doğru geçildiğinde çatı formu da karmaşıklaşmaktadır. Ayrıca bu dönemde cihannüma denemeleri olarak değerlendirebileceğimiz ışıklıklı çatı arası katlar da bulunmaktadır. Çatıların ana strüktürü ahşap elemanlardan kurulmaktadır. Cephede açıkta kalan bazı çatı kirişleri de öylece bırakılarak karakteristik bir görünüm oluşturmaktadır. Bununla birlikte açıkta kalan bu elemanların yine ahşap elemanlarla kaplandığı örnekleri de mevcuttur. Oturtma çatı olarak sistemi kurulan üst örtüde kaplama malzemesi olarak da ahşap eleman tercih edilmiştir. Önceki dönemlerde çatı ahşaplarında farklı türlere rastlanırken sağlamlık açısından son dönemlerde ve restorasyon uygulamalarında 1.sınıf çıralı çam kerestesi uygulanmaktadır. Cumba çatılarında bitişi vurgulamak ve yapı görkemini artırmak amaçlı çift alın tahtası uygulaması görülmektedir. Aynı şekilde kalkan duvarlı çatılarda da bitiş elemanı olarak alın tahtaları tercih edildiğini görmekteyiz. Çatı saçak altları ahşap kaplama, saçak ucundaki eğrisel formlu süslemeler de ahşap malzemeden tercih edilmektedir. 


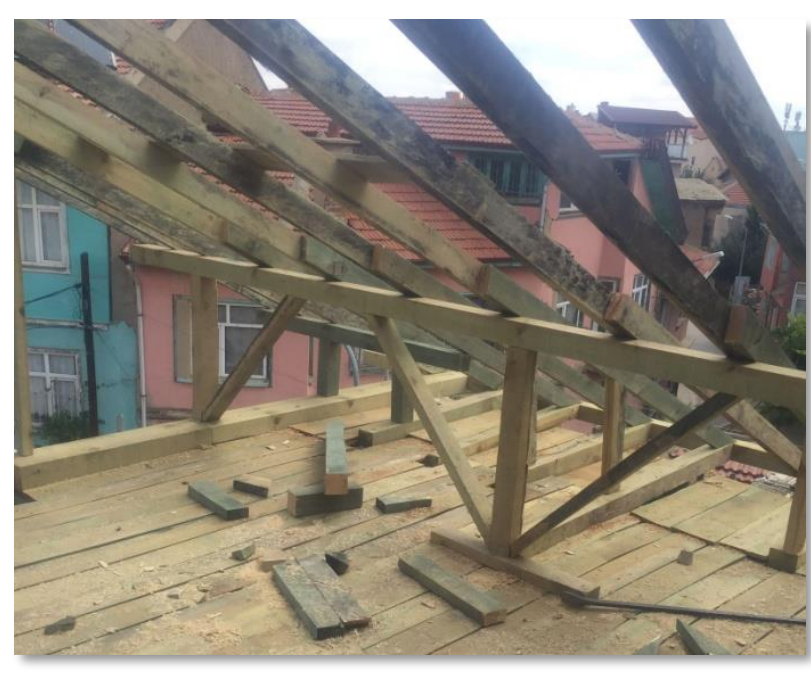

Fotoğraf 19. Süleymanağa Sokak ahşap oturtma çatı (kişisel arşiv, 2018)

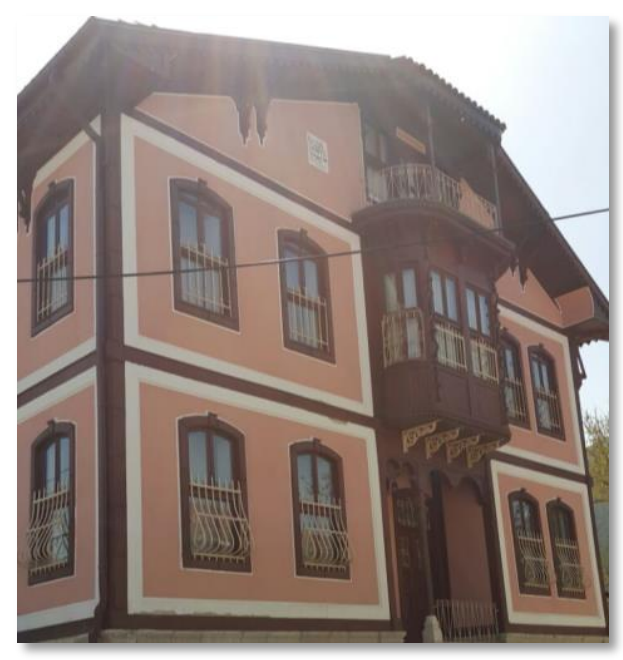

Fotoğraf 20. Eskikale Mahallesi ahşap saçak altı ve alın kornişi (kişisel arşiv, 2015)

Çatı sistemi kurulurken ana taşıyıcı olarak

kullanılan ahşaplar görünmeyeceği için emprenyeli olarak tercih edilirken, çatıda süsleme elemanı olarak kullanılan ahşaplar dış mekâna uygun mat vernik ve koruyuculu olarak uygulanmaktadır. Böylelikle ahşap malzemeyi uzun ömürlü olarak hem strüktür elemanı hem de süs elemanı olarak görmek mümkündür.

\section{SONUÇ VE DEĞERLENDİRME}

Akşehir özelinde geleneksel konut dokuları zaman içerisinde farklı üsluplarla betimlenebilecek şekilde değişikliklere uğramıştır. Tüm bu değişimler yerinde yapılan gözlem ve incelemelere dayanarak cephedeki ahşap elemanlar üzerinden aktarılırken bu durumun kültürel miras olarak önemlerine değinilmiştir. Bu bağlamda konut mimarisindeki dönemsel üsluplara göre kullanımları çeşitlenen cephedeki ahşap elemanlara bakıldığında;

*Eski mimari yapıların yapısal elemanlarının karakteristik bir dili olduğu unutulmaması gerekmektedir. Çünkü bunlar döneminin mimari üslubunu anlamamızı sağlayan elemanlardır.

*Cephede ahşap elemanlar incelenirken kullanım alanı ve amacına göre ahşap malzeme seçilmesi önerilmektedir. Çatıda ve cephede ana strüktür malzemesi olarak kullanılan 1.sınıf ahşaplar taşıyıcılık açısından önem arz etmektedir.

*Ahşabın bozulma-çürüme gibi durumları göz önüne alınarak koruyucu ve emprenyeli olarak kullanılması önemlidir.

${ }^{*}$ Cephedeki ahşap açıklıklar (kapı-pencere gibi) plan şeması ile ilgili ipuçları vermektedir. Özellikle sokak sağlıklaştırma projelerinde bu gibi durumlara dikkat edilmeli yapının özgün haline uygun müdahale yöntemleri benimsenmelidir.

*Ahşap elemanlar cepheye hareket ve estetik katmaktadır. Bu özellikleri düşünülerek cephe organizasyonuna etki eden ahşapların detaydaki konumları değiştirilmeden değerlendirilmesi gerekmektedir.

*Yapıda izine rastlanan ahşap elemanlarla ilgili detaylı ve doğru değerlendirme yapılmadan restorasyon çalışmalarına başlanmamalıdır. 


\section{Kaynakça}

Anonim. (1975). Akşehir Müze Müdürlüğü. Tescil Fişleri. Akşehir.

Bookchin, M. (1999). Kentsiz Kentleşme, İstanbul: Ayrıntı Yayınları, 36.

Demirci, Y., (1998). Geçmişten Günümüze Akşehir, Sanatsal Mozaik Dergisi, İstanbul, 3-18.

Gençer, N., (1995). Akşehir Eski Evleri, Ankara, 6.

Karaman, A., (1998). Kentsel Bir Miras Olarak Akşehir, Sanatsal Mozaik Dergisi, İstanbul, 3-26.

Kiper, H.P. (2006). Küreselleşme Sürecinde Kentlerin Tarihsel-Kültürel Değerlerinin Korunması: TürkiyeBodrum Örneği, İstanbul, Sosyal Araştırmalar Vakfi, 25.

Öncü, A., Weyland, P. (2007). "Küreselleşen Kentlerde Yaşam Alanları ve Kimlik Müdahaleleri”, Mekân, Kültür ve İktidar: Küreselleşen Kentlerde Yeni Kimlikler, İstanbul, İletişim Yayınları, 86.

Özsait, M., (1992). IX Araştırma Sonuçlar Toplantısı (s.377). Ankara.

Şenyiğit, Ö. (2010). Biçimsel ve Anlamsal İfade Aracı Olan Cephelerin Değerlendirilmesine Yönelik Bir Yaklaşım: İstanbul'da Meşrutiyet ve Halaskargazi Caddeleri'ndeki Cephelerin İncelenmesi (doktora tezi), Yıldız Teknik Üniversitesi Fen Bilimleri Enstitüsü, İstanbul, 17.

Umar, B., (1993). Türkiye'deki Tarihsel Adlar. İstanbul.

Ünal, N. (2017). ‘Geleneksel Yapı Malzemeleri', Sanatın Yolculuğu, İstanbul.

Yayınoğlu, P.E., Susar, A.F. (2008). Kent, Görsel Kimlik ve İletişim, İzmit: Umuttepe Yayınları, 18. 